\title{
DIE ETIEK - EERBIED VIR DIE MENS SE LEWE
}

\author{
Prof H W Snyman \\ M B Bch (Wits)
}

\author{
M D Gronigen, \\ Dekaan, Fakulteit Geneeskunde, \\ Universiteit van Pretoria
}

\section{Voordrag by Studente se Kliniese Kongres met tema: Mammakarsinoom Fakulteit Geneeskunde, Universiteit van Pretoria, April 1980}

\section{$\mathbf{O}^{-1}$} m die etiek na behore oop te viek, sou 'n eie en groot opdrag wees, te groot vir die beperkte tyd beskikbaar. Die etiek word dus benader binne die gestelde gedagtegange en benaderings by hierdie simposium.

Wat beteken die woord Etiek? Afgelei van die Griekse woord Ethos, dui dit op die morele of sedelike gebruik. Dit word gestel as: die wetenskap en beginsels van morele gedrag of sedelike norme. Dit is dus 'n sedeleer. Vir ons is dit 'n uiting van 'n gefundeerde gewete.

In ons gedagtewêreld en in ons gemoedslewe, kan ons die volgende fases in sy vorming onderskei:

Die nog ongevormde bewussyn (soos by die dier, die jong kind); wat aanloop tot

die wete $=$ kennis, as kernbegrip vir ons term wetenskap; as aanloop tot

die gewete, as 'n psigiese funksie en 2 e dimensie van menswees;

wat op sy beurt aanloop kan wees tot die reg en wette wat uit die 2 voorafgaande ontspruit.

Skematies kan ons dit soos volg stel: wete gewete wette

norme, tradisies, gebruike,

die gemene reg

\section{Etiek}

Uit professionele kennis, algemene etiek, morele wysbegeerte, teologie

\section{Samesnoerende}

professionele gewete

By die nog ongevormde bewussyn - soos by die dier en by die jong kind - word gedrag instinktief bepaal; dit hoef slegs op 'n prikkel te handel. Sodra die selfbewussyn kom, kom ook die kennis - uit skoling, opleiding, en opvoeding - met die voorskrifte vir gedrag. Hierop kan volg die keuse van handeling of gedrag, 'n keuse tussen wat as "goed" en wat as "sleg" beskou word. Kennis plus keuse (tussen reg en verkeerd) bied vir ons die gewete.
Die groot vrae op ons pad is: "Wat is die Mens?" maar belangriker nog "Wie is die Mens?" - vrae wat al eeuelank weerklink en opnuut deur elkeen wat die lewe ontvang, gevra word. "Wat die lewe ontvang" is die kernbepaler, want die vrae wentel om die sin of die betekenis van die Lewe en van die dinge wat die mens en in ons geval wat die siek mens of pasiënt (patiens = die lydende) - in sý lewe moet ondergaan. Dit gaan vir die mens ook intiem om wat daarna, ná die Lewe, sal volg, die transendensie, want die mens is die enigste vorm van lewe wat weet dat hy sal sterf.

Die brandpunt vir ons as beroep is dus die Lewe, vandaar die tweede deel van die opdrag: eerbied vir die mens se lewe. Vanwaar kom die stelling? Vir die jong geslag, wat in hoofsaak hierdie gehoor uitmaak, is die naam van Albert Schweitzer miskien onbekend, miskien slegs vaag bekend. Dit is egter ' $n$ naam wat in sy eie tyd weerklink het, in Europa, in Amerika, ja oral. Van groot formaat as geneesheer, as wysgeer, en as musikus, stel Schweitzer 'n roemryke akademiese en breed kulturele loopbaan opsy om in Afrika - in Gabon by Lambourene - 'n hospitaal op te rig en voltyds as geneesheer te kom werk. Groot is sy kennis (die wete), daaddruftig is sy gewete. Van hom dan kom die slagspreuk aangebring bo die ingang tot sy hospitaal "Ehrfurcht vor dem Leben"' (Eerbied vir die Lewe). L.W. Dit het alle vorme van lewe ingesluit, tot selfs die siektedraende vlieë en muskiete. Hierdie uiterste standpunt kan ons nie onderskryf nie, vandaar die wysiging in ons taak. t.w. "Eerbied vir die Menslike Lewe" soos pragtig uitgewerk deur dr Gawie Roux in sy MDproefskrif met daardie titel aan die Universiteit van Pretoria.

Dit bring ons terug by die vraag "Wat is hierdie mens?" Die vraag is voorwerplik gestel en, as voorwerp van ons kongrestema, ken ons haar in haar bou, in haar funksie, in haar siekwording, haar siekteverskyning; ons kan haar omskryf, haar siekte gradeer en tot in haar seltipe bepaal. Ons weet dus baie van wat sy is, maar weet ons wie sy is? Sy, eenmalige mens - nooit sal sy presies herhaal word nie - sy as volwaardige lyfgeesteswese, as eenling in persoon, met 'n bewussyn van haar self, die bewuste Ek. En dié Ek met 'n langsaam en moeisaam verworwe maar diepgesetelde eiewaarde, maar wat weet dat sy sal sterf. En nou met 
die kankerdiagnose, skerp bewus en bedreig dat die nuutgevonde Ek en sy eiewaarde vroeg tot niet sal gaan. Dit is die menslike toestand met eienskappe wat hom van al die ander lewensvorme onderskei. Die vraag dus "Wie is sy", strek verby die biologie tot in die etiek, norme, waardes en die geloof wat buite die wentenskaplike bereik geleè lê, maar vir die bewuste mens in sy lewenswandel noodsaaklik is.

Treffend is dan dikwels die voorbeeld wat ons pasiënte vir ons stel: bewus van ons diagnose en sy doodskaduwee, styg hulle nog bo die wanhoop uit en doen heidhaftig wat hulle nog kan doen.

Bewus van hierdie besondere eienskappe en hierdie groot waardes in die mens se lewe, spruit dus ons gesindheid en beandering as beroep: "Eerbied vir die Menslike Lewe'". My kennis van haar mammakarsinoom is maar aanloop tot my kennis van Haar waarvan haar mamma maar deel uitmaak. Gesien haar funksie, oor duisende jare gevorm as bron van voortplanting, en as deel daarvan haar essensiële vroulikheid en aantreklikheid vir die geslagsmaat, is die mamma nie maar gerieflik af te skryf as net maar 'n orgaan soos byvoorbeeld ' $n$ nier nie - dit is 'n wesenlike onderdeel van hoe sy haarself as vrou sien en ondervind - die eiewaarde waaruit sy moet leef; die eiewaarde as verlengstuk tot haar man, en verder tot haar kinders.

Wanneer u dus die somatiese diagnose van 'n kanker in die mamma gestel het, gaan soek die vrou agter die mamma: wie sy is, hoe sy voel, wat sý sê oor al die verborge implikasies van u bevinding en oor wat $u$ vir haar en met haar wil doen. Wat is háár keuse?

Die verhouding tussen siek mens en arts bring altyd 3 vrae:

Wat is verkeerd? Wat kan gedoen word? Op daardie twee vrae beskik u oor antwoorde wat die wetenskap u bring.

Met $u$ kennis en aanvoeling van haar as persoon sal $\mathrm{u}$ in $\mathrm{u}$ professionele gewete ook die beste antwoord op die derde vraag bekom: Wat behoort ek vir haar te doen? 